\title{
ICT Strategic Planning in Malaysia Public Research Institute
}

\author{
I. S. Ishak, R. A. Alias, U. Adam, and Z. Suradi
}

\begin{abstract}
ICT Strategic Planning (ICTSP) is important to an ICT manager because their wisdom in managing ICTSP implementation is being use as one of their performance indicators. Although there are many benefits for implementing ICTSP, ICT managers are still facing problems in coping with the development of ICTSP in their organization. Research Institute has unique characteristics that need to be look deeper to maximize the impact of their ICTSP implementation. This paper presents the comparison of research institutes characteristics against business organizations and institutes of higher learning. A survey questionnaire was sent to the Heads of IT in IPA. The results of the status study of ICTSP development and implementation in Malaysian Public Research Institute and Government Agencies (IPA) provide a better understanding of their requirements. The finding of the study showed that one of IPAs ICTSP aim is to promote innovation in their organization since they are a dynamic and innovative organization. The research also revealed that even though IPA had experienced in ICTSP development and implementation, they were still facing several problems in developing and implementing ICTSP using existing methodologies. The problem is related to the level of easiness and completeness of methodology used and the comprehensiveness of blueprint produce to gain the requested budget from the sponsor. In addition, the research also suggested that there is a need to customize the existing ICTSP methodology to fulfill research institutes unique characteristics and to maximize ICTSP impact to promote innovation in the organization.
\end{abstract}

Index Terms-Strategic information systems planning, ICT strategic planning, SISP methodology, research institutes.

\section{INTRODUCTION}

Usually the purpose for an organization to develop an ICT Strategic Plan (ICTSP) blueprints is to generate ICT strategies. These strategies will be used to direct organizations towards achieving their ICT goals. There existed several methodologies, methods, techniques and tools that can be used to develop ICTSP blueprint according to the organization needs and objectives. Many ICT application developers found that ICTSP or also known as Strategic Information Systems Planning (SISP) is very useful as it provides a systematic guideline for generating ICT strategies. Even though there are many benefits of ICTSP that had been

Manuscript received March 20, 2013; revised July 15, 2013. This work is part of PhD work of Irny Suzila Ishak.

I. S. Ishak is with the Universiti Selangor, Bestari Jaya Campus, 45600, Selangor, Malaysia (e-mail: irnyr@ unisel.edu.my).

R .A Alias and U. Adam are with Universiti Teknologi Malaysia, UTM Skudai, 81310, Johor, Malaysia (e-mail: alinda@utm.my, umussaadah@gmail.com).

Z. Suradi is with Asia-e University, Dataran Kewangan Darul Takaful, No 4, Jalan Sultan Sulaiman, 50000 Kuala Lumpur, Malaysia (e-mail: zurinah.suradi@aeu.edu.my). highlighted in previous research, there still exists challenges faced by organizations during the ICTSP development and implementation period [1]-[4].

ICTSP methodologies can be categorized using several methods. Firstly, ICTSP methodologies can be classified into alignment methodology. In this methodology, the organizational IS objectives are aligned against the organizational goals. In contrast the impact methodology can be used to create and justify new uses of IT [5]-[7]. Secondly, SISP approach can be classified based on the formalization and effectiveness classification matrix [8]. Thirdly is by categorizing ICTSP methodologies into two major categories; general methodology and the methodology developed for use in specific contexts. The contexts in the second category are the context of business organizations, government agencies, and educational institutions [2], [4].

Malaysian Public Research Institute and Government Agencies (IPA) is an organization under the public sector category. As public sector agencies, the ICTSP development and implementation in IPA must be referred to the Administration Modernization and Management Planning Unit (MAMPU). MAMPU is the monitoring agency that is responsible to monitor the ICTSP implementation in Malaysian public sector. IPA has to be dynamic and receptive in their ICT approach since they are expected to lead in innovation. The IPA direction should be in lined with the Malaysian National Transformation Agenda where one of the focuses is on the innovative citizen-centric model of public service delivery [9]. This agenda require changes in the role of ICT to enable effective utilisation and application of ICT across multi-faceted service delivery and internal government operations. This is important because the next wave of ICT will focus more on collaborative and co-operative arrangement of open consultation, open data, shared knowledge and expertise, consolidation of shared services and enhanced horizontal application. Besides that, the new government ICT landscape will not only focus on citizen-driven and employee-centric but also need to focus on the dynamic and transformational dimension where it requires better blend of planning and management.

In order to cope with today's dynamic environment challenges, ICTSP methodologies need to be modified and revised according to the uniqueness of the context. Several revisions need to be conducted especially in organizations that are based on creative and innovative environment. Normally, in a traditional ICT Strategic Planning, it will begin with Phase 1: Business Strategic Planning; Phase 2: ICT Strategic Planning and Phase 3: ICT Strategic Planning Implementation. However, with the evolvement of internet technologies, these assumptions are not always true. The 
dynamic changes of technology make some people think that it is not appropriate to plan. This may be due to that the future cannot be predicted anymore, the rapid changes in ICT role and the top management might not know everything. Moreover, the employees are observed to be more close to the customers, vendor and business partner then before. This allows the employee to have more information or knowledge about the industrial needs and what the market demands for.

In addressing the environment dynamic changes and the growing expectation of the ICT strategies impact, the ICTSP end products should be able to detect the significant changes in a dynamic environment, quickly respond to change and must not dependent on just one strategy [10], [11].

\section{RESEARCH INSTITUTES}

As the importance of PSICT approach and context to PSICT success had been highlighted in previous research [2], [4], [12], [13], the characteristic of Research Institutes had been explored to identify the differences and similarities of Research Institutes as compared to other type of organization i.e. business organization and institute of higher learning (IHL). The organizational characteristics aspect of comparison is as tabulated in Table I.

This comparison showed that research institutes are unique as compared to other type of organization [14]-[20]. A research institutes should posses the following aspect: creativity, innovativeness, productivity, and responsiveness since the organization will continuously to evolve within its environment plus dynamical in nature where [18]-[20]. The institute needs to be quick in response to the changes in environment and technology development so that it can seize and exploit opportunities. These are in addition to their normal roles which are planning, administration and conducting research and development.

Common organization structure use in research institutes is the Matrix Organization. In this type of organization, the power is decentralized and existed dual-authority relationship. This indicates that there is a need to balance the power between program manager and function manager. The focus groups in research institute are Supervisor, Chief Executive, Functional Manager, Program Manager, Stockholder, Federal Administration, Citizen, Tax payer. This is because research institutes are responsible to produce product and services for citizen and taxpayer. Research institutes usually report to Federal Administration and Stakeholder.

The management style in research institutes are technocratic and democracy which may fit the description of Management by Objectives (MBO). MBO is a process of defining objectives within an organization so that management and employees agree to the objectives and understand what they need to do in the organization in order to achieve them. The type of task in research institutes are usually of non-routine tasks.

As the characteristic of research institutes is unique as compare to other type of organization, they require unique method of planning. The dynamically evolve environment of new technology and innovation that they have to produce also sometimes make the research and development effort in research institutes do not have consistent planning [19]. The organization needs to be attentive all the time and must have the capability to capture and exploit the emerging opportunities.

TABLE I: THE COMPARISON BETWEEN THREE TYPES OF ORGANIZATION

\begin{tabular}{|c|c|c|c|}
\hline Element & $\begin{array}{l}\text { Business } \\
\text { Organization }\end{array}$ & IHLs & $\begin{array}{l}\text { Research } \\
\text { Institutes }\end{array}$ \\
\hline $\begin{array}{l}\text { Type of } \\
\text { organizatio } \\
\text { n }\end{array}$ & $\begin{array}{l}\text {-Entrepreneurship } \\
\text { Structure }\end{array}$ & $\begin{array}{l}\text {-Professional } \\
\text { Bureaucracy }\end{array}$ & $\begin{array}{l}\text {-Creative, vital, } \\
\text { ongoing }\end{array}$ \\
\hline Goal & $\begin{array}{l}\text {-Utilitarian goal } \\
\text {-Clear and unique } \\
\text { goal }\end{array}$ & -Normative goal & $\begin{array}{l}\text {-Seize and } \\
\text { exploit } \\
\text { opportunities }\end{array}$ \\
\hline $\begin{array}{l}\text { Organizati } \\
\text { on } \\
\text { Structure }\end{array}$ & -Hierarchical & \begin{tabular}{l|}
-Less \\
hierarchical. \\
-There are \\
informal \\
organization that \\
have power in \\
universities
\end{tabular} & $\begin{array}{l}\text {-Matrix } \\
\text { organization }\end{array}$ \\
\hline Power & $\begin{array}{l}\text {-Centralized, } \\
\text {-The strategic } \\
\text { decision is in the } \\
\text { CEO hand }\end{array}$ & $\begin{array}{l}\text {-Involve many } \\
\text { stakeholders } \\
\text {-The strategic } \\
\text { decision involve } \\
\text { professors, senate } \\
\text { board of } \\
\text { directors, Vice } \\
\text { Chancellor, } \\
\text { senior } \\
\text { administrator, } \\
\text { faculty and in } \\
\text { several cases } \\
\text { student }\end{array}$ & $\begin{array}{l}\text {-Decentralized } \\
\text {-dual-authority } \\
\text { relationship } \\
\text {-balance power } \\
\text { between } \\
\text { program } \\
\text { manager and } \\
\text { function } \\
\text { manager }\end{array}$ \\
\hline $\begin{array}{l}\text { Focus } \\
\text { Group }\end{array}$ & $\begin{array}{l}\text {-Customer } \\
\text {-Stakeholder } \\
\text {-The public } \\
\text { community }\end{array}$ & $\begin{array}{l}\text {-Government } \\
\text { that give } \\
\text { budget } \\
\text {-Other sponsors } \\
\text {-Student and } \\
\text { family } \\
\text {-Faculty, } \\
\text { administrator, } \\
\text { staff } \\
\text {-Employer } \\
\text {-Resident } \\
\text { community, } \\
\text { official } \\
\text { community and } \\
\text { business } \\
\text { community }\end{array}$ & $\begin{array}{l}\text {-Supervisor } \\
\text {-Chief Executive } \\
\text {-Functional } \\
\text { Manager } \\
\text {-Program } \\
\text { Manager } \\
\text {-Stockholder } \\
\text {-Federal } \\
\text { administration } \\
\text {-Citizen } \\
\text {-Tax payer }\end{array}$ \\
\hline Role & $\begin{array}{l}\text {-Optimize } \\
\text { resources to } \\
\text { achieve economic } \\
\text { goal }\end{array}$ & -Normative role & $\begin{array}{l}\text {-Planning, } \\
\text { administration, } \\
\text { R\&D }\end{array}$ \\
\hline $\begin{array}{l}\text { Manageme } \\
\text { nt Style }\end{array}$ & $\begin{array}{l}\text {-Democracy } \\
\text {-authoritarian } \\
\text {-Technocratic }\end{array}$ & -Bureaucratic & $\begin{array}{l}\text {-Technocratic } \\
\text {-Democracy } \\
\text { MBO }\end{array}$ \\
\hline Task & $\begin{array}{l}\text {-Depend on the } \\
\text { tasks, some are } \\
\text { routine, others are } \\
\text { not routine }\end{array}$ & $\begin{array}{l}\text {-Routine and } \\
\text { non-routine } \\
\text { tasks }\end{array}$ & $\begin{array}{l}\text {-Non-routine } \\
\text { tasks }\end{array}$ \\
\hline
\end{tabular}

There are two types of research institute in Malaysia: public and private institute. The Public Research Institutes can be divided further into Government Agencies and Public Research Institutes (IPA) and Research Institutes in Institutes of Higher Learning. One of the roles of IPA is to carry out $\mathrm{R} \& \mathrm{D}$, provides technical and consultancy services, offers diagnostic services, business joint-venture and licensing. 
According to MASTIC, there are 33 Government Agencies and Public Research Institutes [21].

Public Research institutes (IPA) play a critical role in forging the interface between science advancement and the industry sector. Basically the Malaysian IPA performs mainly downstream, applied research in order to be relevant to their target customers or they are focused in undertaking activities that satisfy their departmental remits. Their core research areas range from primary commodities, industry and engineering to national healthcare. The 2008 National Survey of R\&D in Malaysia revealed that, IPAs that involved in agricultural sciences dominated the top national $R \& D$ expenditure by field of research [22] .Other main areas of research focus include forestry sciences, material sciences, engineering science and biotechnology. Also, most of the research conducted is applied research, rather than basic or experimental development research. IPA account for almost $5 \%$ of the nation's total R\&D expenditure and about $25 \%$ of the country's total number of research personnel [22].

The objectives of this study are to discover current status of ICT Strategic Plan (ICTSP) development and implementation at the Public Research Institutes and Government Agencies (IPA) and to identify unique characteristics of ICTSP implementation in research institutes. Besides that, this study also aims to identify the effectiveness of ICT Strategic Planning (ICTSP) implementation practice in Malaysia research institutes using existing ICTSP methodology.

\section{RESEARCH Methodology}

A survey to study the ICT Strategic Plan (ICTSP) was conducted in 32 Public Research Institutes and Government Agencies (IPA). The source of the IPA list is from Malaysia Science and Technology Information Centre (MASTIC). Out of this, 27 IPA's responded to the questionnaire distributed and returned the forms. The survey was designed to be exploratory in nature. It aims is to identify the status quo of the IPA ICTSP development and implementations, and the problems faced in developing and implementing ICTSP in IPA. Besides that, the study is also conducted to find out whether the existing ICT strategic planning methodologies produce effective ICT strategy and contributes to innovation in the research institutes.

The Operating Framework for this study began with the design phase as the first phase. The objective of the design phase is to design the questionnaire for the initial data collection. The deliverable of this phase is an open-ended questionnaire. The questionnaire was designed this way to allow the respondents describe the status of ICTSP implementation in IPA and elaborate what development and implementation problem arise using current ICTSP methodology.

The second phase of this study is the phase of data collection. In order to get the information needed, a purposive sampling technique was used. The selection of the Head of ICT Division as the respondent is based on the rationale that the Head of ICT Division is usually the person most knowledgeable about ICT Strategic Planning process within the organization. The questionnaires were distributed to Head of ICT in 32 research institutes.

The third phase of this study is the analysis phase. The objective of this phase is to analyze data collected using statistical methods and qualitative methods. Data was analyzed using descriptive statistical methods and qualitative analysis techniques. The result of this phase is a descriptive statistical analysis and data analysis produced through constant comparative method and the 'content analysis' method.

The fourth phase is the phase of documenting the results. The findings of the study were sent to the respondent for verification. Documented findings include information about the IPA ICTSP status information and information about the IPA ICTSP development and implementation problems. The documentation also includes discussion and conclusion of the study.

\section{RESUlTS AND DisCUSSION}

Analysis of the ICTSP development and implementation status at the Public Research Institute and Government Agencies (IPA) was based on 27 responses from 32 IPA respondents. This showed the percentage of respondents who gave feedback is around 84 percent. Based on literature review, a sufficient amount of feedback was evaluated based on the type of cases or subjects studied and methods of data collection. The type of subject under study was based on units of analysis of individual and organizational level. The study of the organization usually has a response rate of less than the study of the individual, where the responses rate 15 percent were accepted to study organizational unit of analysis [23], [24]. As the focus of the organization is usually the workplace, factors such as busy at work, privacy, regulations and organizational policies may cause the rate of questionnaire responses to be reduced [25].

The study shows that 23 out of 27 IPA have developed ICTSP in their organization. The level of ICTSP experience in most IPA is in the evolving level (refer to Fig. 1). Most IPA began to develop ICTSP between the periods of year 2000 until 2006. The respondents felt that their organization is in the evolving level since that their planning procedure had been developed in ICTSP exercise. However, the respondents also indicated that planning process is still in needs to be improved from time to time. On the other hand, 26 percent of IPA suggested that their ICTSP is at the emergent level. This implied that the procedures and the policies for conducting planning had just begun to emerge in the organization. In addition, this also indicated that there is little SISP experience among the participating managers. Further, only 9 percent of IPA stated that their ICTSP is at the matured level. This showed that they have a long history of planning activity and had much SISP experience among the participating executives. Besides that, they also pointed out that they have a well-developed policies and procedures for conducting planning in their respective organization.

Most of the IPA also indicated that they have developed the ICTSP themselves or in-house. This showed that the ICT manager had built a confidence in them to develop ICTSP using MAMPU Methodology and/or other related techniques. Usually, the IPA took about six months to develop the ICTSP. 
This is because they need to get approval and budget from MAMPU and the Economic Planning Unit (EPU).

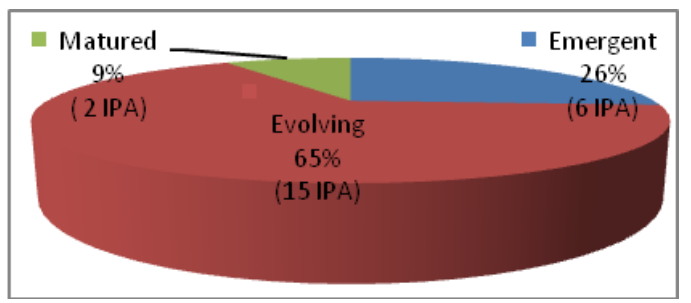

Fig. 1. IPA level of experience in developing ICTSP.

About 74.1 percent of the 27 IPA stated that one of their ICTSP aims is to produce ICTSP that can promote innovation in organization (refer to Fig. 2). This implied that IPA expected the ICT strategies produced from ICTSP can enhance innovation in organization.

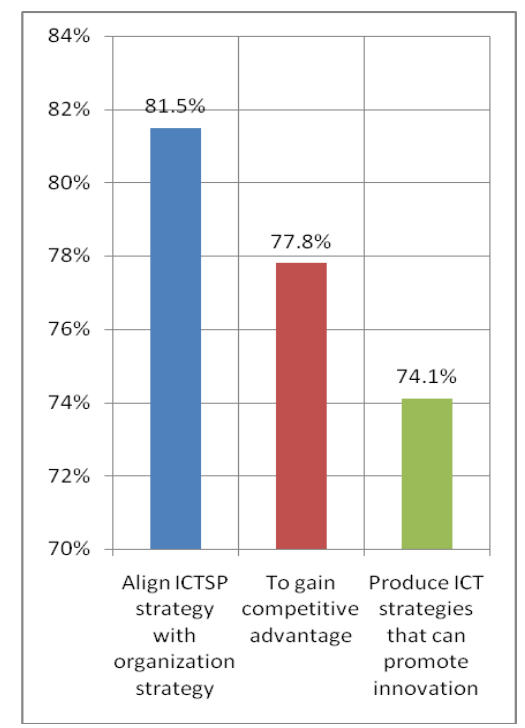

Fig. 2. The aim of ICTSP development in IPA.

However, the respondents indicated that most of these IPA took about 5 to 10 years to implement an ICTSP. This is in contrast to the suggested timeframe for ICTSP implementation period which is about 1-2 years if the organization wants to be a creative and innovative organization [18]. This denotes that a quick response time is needed as to be current with the advancement of ICT technology. In addition, in order to improve and be quick in response time, McNurlin suggests that organizations should divide the ICT strategic planning implementation into several 'strategic envelopes' [18]. This will enable the organization to be more responsive to any opportunities emerging from the rapid technology development and dynamic changes of environment. The 'Strategic envelope' is referred to as ICT strategies that had been divided into small projects that will be tested through experiments and prototyping. The aim of the 'strategic envelope' is to ensure the successfulness of any ICT strategic project implemented.

Based on the study conducted, ICTSP method or methodology are most often used as a Key Performance Indicator (KPI). About 59.3 percent or 16 IPA indicated that a methodology was selected for their ICTSP development in order to fulfill the organizational KPI requirements (refer Fig. 3). This followed by MAMPU Methodology with 51.9 percent and SWOT analysis (48.1 percent).

One of the factors why KPI methodology is most often being used as a methodology might be because government agencies used KPI to measure their annual performance. Moreover, IPA is answerable to government for their organizational performance. In addition, all government agencies need to produce ICT Strategic Planning blueprints that has been proposed by MAMPU and known as MAMPU Methodology. This methodology has been considered as one of the main references in the ICTSP development in IPA.

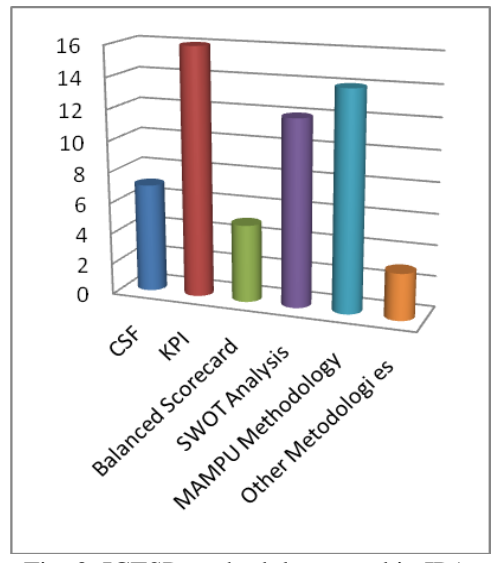

Fig. 3. ICTSP methodology used in IPA.

SWOT Analysis is still a popular technique used among the IPAs, even though there are other techniques like "Strategy Canvas" and "Blue Ocean Strategy" that can be used to evaluate organizational standings in terms of strength, weaknesses, opportunity and threats. Moreover, the "Strategy Canvas and Blue Ocean Strategy" can be used to identify unique and innovative strategy. The strategy used will helps the organizations to identify what aspects need to be created, increased, reduced or eliminated.

The study also demonstrates that 18 IPA involved the ICT Unit/Department Executives in ICTSP development. This is followed by the department representatives (refer to Fig. 4). About 15 IPA or 60 percent of IPA involving the top management in their ICTSP development and about 52 percent of IPA also involved CIO in their ICTSP.

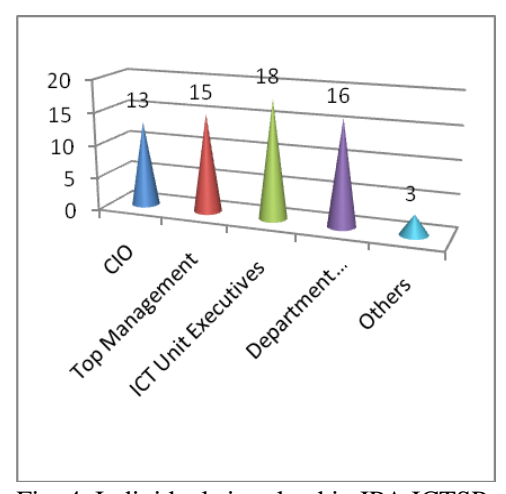

Fig. 4. Individuals involved in IPA ICTSP.

By positioning the ICT Unit directly under the top management monitoring had help IPA to easily gain top management commitment and that will make it easier for the ICTSP projects to receive the allocated budgets. However, some respondents indicated that as IPA is under government agencies category, the budget approval will depends on 
government budgets availability. Sometimes the budget received is less than the requested budgets which in turn make the ICTSP implementation become a bit difficult.

If we compare our study with that of previous research on 'Study of ICT in Government Agencies 2010', this study shows that lack of expert human resource in ICTSP development is still being experience in IPA. This situation might be related to the easiness and completeness of current practice ICSTP methodology to guide the ICTSP development and implementation process. Besides that, not enough budgets are also identified as persistence issue that is always raised by ICT Managers in IPA. This problem might be related to the comprehensiveness of ICTSP blueprint produced to get the requested budget from the sponsor. Another problem identified is in getting collaboration from the top management to attend for a brainstorming session which may contribute to time constraint issue for ICTSP development. In turn, the delayed in brainstorming session affects the ICTSP development and implementation schedule. Other problems that were detected are regarding user commitment and inter-department system integration. This usually occurs when the IPA develops the ICTSP for the first time or development process is guided by less experienced ICT Executives.

This study also identifies that some of ICTSP problems that still persist or are repeated in the ICTSP implementation phase. The main problems identified among IPAs are lack of human resource expert and not enough budgets faced while implementing ICTSP. These problems become a constraint for IPA to implement ICTSP as according to schedule. The top management that was less concerned about the ICTSP planning and implementation will affect the implementation continuity. The effect will become more severe when the ICT Managers move to another department or organization or retire from service. Besides that, lack of top management commitment will also affect user commitment. Moreover, the lack of expert in ICT department will also influence the inter-department system integrations.

The lesson learned from this study is that most IPA had experienced in ICTSP development and implementation. Some of the research institutes had produced several ICT innovation strategies as a result of their ICTSP implementation. Despite the IPA experience and achievement, they still face difficulties in ICTSP development and implementation process using the selected methodology. The study found that 21 from 23 IPA are facing problems either in the developing stage or implementing phase of ICTSP in their organizations. The problems usually occur because of lack of human expertise and budget constraint. Although lack of human expertise and budget limitation is not the main problem as indicated in previous ICT strategic planning research (Noor Azizi et.al, 2007; Yaakub et.al, 2005; Teo and Ang, 2001, Lederer and Sethi, 1988), lack of human expertise and budget limitation problem had been identified as one of SISP problem in previous research (Pita et al, 2009; Wilcocks, 2000; Ward and Griffith, 1998; Cherpa and Verner, 1998). Lack of human expertise in ICT Strategic Planning might happened when the ICT planning steering committee and IT unit/ department did not have enough knowledge to develop and implement SISP smoothly due to unclear methodology and lack of training. According to Pita et.al (2008), budget constraint usually happen in ICT Strategic Planning development and implementation when the ICT champion cannot get full support from the top management due to misalignment.

The aims of ICTSP in Malaysia IPA are mostly to align ICT objective with organization objective. However, ICTSP in IPA is also expected to enhance organization competitive advantage and contribute to the innovation research institutes. This is because research institutes dynamic environment required them to be more responsive to opportunities and rapid technology development. The existing ICTSP methodology may need to be customized to fit the innovative and dynamic research institutes environment. ICTSP Methodology also needs to be more detail to guide the ICTSP developer on how ICTSP can be used for promoting innovation in the research institutes. In order for research institute to become more creative and innovative organization, the timeframe for ICTSP implementation period in research institutes also need to be strictly observed to about 1-2 years. This is to ensure the ICTSP produce is not obsolete and research institute can seize new opportunities.

\section{REFERENCES}

[1] F. N. Al-Aboud, "Strategic information systems planning: A brief review," International Journal of Computer Science and Network Security, vol. 11, no. 5, May 2011.

[2] Z. Pita, F. Cheong, and B.Corbitt, "Major issues in SISP: insights into the main reason of SISP failure," in Proc. 17th European Conference on Information Systems (ECIS 2009), Verona, Italy, June 8-10, 2009.

[3] N. A. B. Ismail, R. H. R. M. Ali, R. M. Saat, and H. M. Hasbollah, "Strategic information systems planning for malaysian public universities," Campus-Wide Information Systems. vol. 24, no. 5, pp. 331-341, 2007.

[4] I. S. Ishak and R. A. Alias, "Designing a strategic information systems planning methodology for malaysian institutes of higher learning (Isp-Ipta)," Issues in Information Systems, vol. 6, no. 1, 2005.

[5] J. Ward and J. Peppard, Strategic Planning for InformationSystems; New York: Wiley, 2002, ch. 1-5.

[6] Pant and Hsu, "Strategic information systems planning a review," Information Resources Management Association International Conference, Atlanta, Georgia, May 21-24, 1995.

[7] A. L. Lederer and V. Sethi, "The implementation of strategic information systems planning methodologies, MIS Quarterly, vol. 12, no. 3, pp. 445-461, 1988

[8] F. Albadri and S. Abdallah, "Strategic information systems planning in UAE organization: SISP approaches classification," in Proc. the European, Mediterranean \& Middle Eastern Conference on Information Systems, 2010.

[9] Malaysian Administration Modernisation and Management Planning Unit (MAMPU). (2011). Information System Planning (2011-2015). [Online]. Available: http:// www.mampu.gov.my/pdf/flipbook/ISPplan2011

[10] P. A. Thomas, "Strategic information systems planning," ASCUE Proceedings, pp. 47-58, 2010.

[11] B. McNurlin, R. Sprague, and T. Bui, Information Systems Management in Practice, 8th Ed., Upper Saddle River, New Jersey: Prentice Hall, 2009.

[12] T. Bechor, S. Neumann, M. Zviran, and C. Glezer, "A contingency model for estimating success of strategic information systems planning," Information \& managemen, vol. 47, no. 1, pp. 17-29. 2010.

[13] A. L. Lerner. (1999). A strategic planning primer for higher education. [Online]. Available: http://www.des. calstate.edu / strategic. html

[14] R. A. Alias, M. H. Selamat, S. Abdullah, and I. S. Ishak, "Strategic information systems planning for IHLs: A preview," presented at the Malaysian Science and Technology Congress 2001 (MSTC Information and Communication Technology Session, Universiti Science Malaysia, Nov. 8-10, 2001 
[15] K. Laudon and J. Laudon, Management information system-new approaches to organization technology, New York: Prentice Hall, 1998.

[16] UCLA IT Planning Project, "Key issues in information technology in higher education," Coopers and Lybrand Consulting Research Report, pp. 1-5, 1996.

[17] Commonwealth Higher Education Management Service, "The Planning Process," Workshop on Strategic Planning in Universities, Aug. 3, 1999.

[18] D. Nobelius. (2004). Towards the sixth generation of R\&D management. International Journal of Project Management. [Online]. Available: http: www.elsevier.com/ locate/ijproman

[19] P. H. Francis, Principles of $R \& D$ Management, AMACOM- A Division of American Management Association, 1977.

[20] W. T. Mallon and S. A. Bunton, "Characteristics of Research Centers and Institutes at U.S. Medical Schools and Universities," Association of American Medical Colleges. June, 2005.

[21] List of Government Agencies and Public Research Institutes. [Online]. Available: http://www.mastic.gov.my/../a326a793-52d6-455e-bc3.. -(accessed Jan. 1, 2011).

[22] J. N. K. John et al., "Unleashing innovation from public research institutes," Study report, A Study for Unit Inovasi Khas, Faculty of Economics \& Policy Science, UCSI, 2011.

[23] A. Baldauf, H. Reisinger, and W. C. Moncrief, "Examining motivations to refuse industrial mail surveys," Journal of the Market Research Society, vol. 41, pp. 345-353, 1999.

[24] D. Tomaskovic- Devey, J. Leiter, and S. Thompson, "Organizational survey nonresponse," Administrative Science Quarterly, 39, pp. 439-457, 1994

[25] T. V. Greer, R. Chuchinprakarn, and Seshadri, "Likelihood of articipating in mail survey research: Business respondents' perspectives," Industrial Marketing Management, vol. 29, pp. 97-109, 2000.

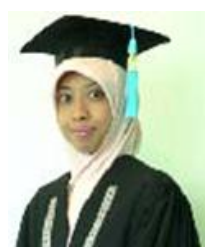

Irny Suzila Ishak received degree in Computer Science from Universiti Teknologi Malaysia (UTM), majoring in MIS. She also earned her master degree in Computer Science (by research) from UTM. Currently she work as lecturer at Faculty of Computer Science and Information Technology, Universiti Selangor. In the same time, she is also pursuing her Doctoral of Philosophy in Information Systems at UTM. Her research interests focus on ICT Strategic Planning, ICT Strategic Planning Methodology, ICT
Innovation, ICT in IHLs and Research Institutes. She is a member of Association of Information Systems.

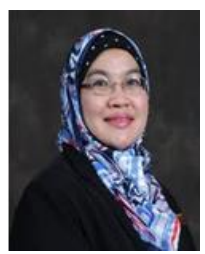

Rose Alinda Alias received degree in Computer Science from Universiy of Miami, USA. She also earned her double master degree (computer information systems and business administration) from Universiy of Miami, USA. She had pursued her Doctoral of Philosophy in Information Systems at University of Salford, UK. Currently she is attached to Faculty of Computing UTM and hold a position as the UTM Deputy Vice Chancellor (Academic and International). Her research area of expertise is in Knowledge Management, Information Systems Strategy \& Planning, and Information Systems Quality. Professor Dr. Rose Alinda Alias is a member of Association of Information Systems.

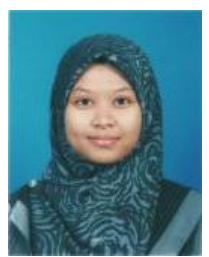

Umussaa'dah Adam holds a Bachelor's degree in Computer Science (SE) from Universiti Teknologi Malaysia and a Diploma in Computer Science (Information Technology) also from Universiti Teknologi Malaysia. In December 2012 she had gone through her viva voce and soon, she will receive her Masters in Computer Science from Universiti Teknologi Malaysia Skudai, Johor. Her research areas are Information System (IS), ICT and Communication and logistics standard data exchange.

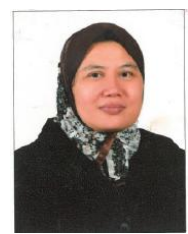

Zurinah Suradi received degree in Mathematics and Computer Science from Oklahoma State University, USA and in Mathematics with option in statistics from West Virginia University, USA. She earned her Doctor of Philosophy in Information Science from University of Strathclyde, UK. Currently she is with School of Information and Communication Technology, AeU. Her research interest focus includesinformation system adoption, management information systems, information system planning and knowledge management. Associate Professor Dr. Zurinah Suradi recent publication was on the critical factors affecting learning management system among on-line learner. 